in a few tubes prior to flocculation, he examined them carefully against indirect light, murmuring to himself 'it isn't so bad', and put the tubes in the refrigerator. The next morning crystals of the ricin protein were clearly visible in two of the tubes.

Kunitz's isolation of some 18 enzymes and precursors in crystalline form from animal and plant tissues and yeast, each with evidence of its purity went far to confirm Northrop's thesis that enzymes are proteins.

Although his name is associated primarily with protein crystallization, Kunitz's contributions and capacity were much broader. In one of his least known and yet more important papers, 'The Kinetics and Thermodynamics of Reversible Denaturation of Crystalline Soybean Trypsin Inhibitor' (J. gen. Physiol. 1948, 32, 241), Kunitz demonstrated by enzymatic and physico-chemical methods that renaturation of the inhibitor yielded a product indistinguishable from the original protein. Using a kinetic approach to the equilibrium reaction from both sides at different temperatures, he obtained clean thermodynamic values for each process. This study laid to rest the prevailing notion that so complicated a process as protein denaturation could not be completely reversible.

On the occasion of Kunitz's being awarded the Carl Neuberg Medal in 1957 by the American Society of European Chemists and Pharmacists, Dr Northrop wrote the following: 'Dr Kunitz possesses to a rare degree the abilitics of a research worker of the first rank in his chosen field - imagination, ingenuity, and persistence, great technical skill, mathematical facility and thorough theoretical knowledge. It is not surprising, therefore, that he has been able to solve almost every problem he has attempted. Some of them are of great importance. The isolation and crystallization of ribonuclease, hexokinase, and desoxyribonuclease placed the protein nature of enzymes in general on firm experimental foundation. In addition, the nucleases have been invaluable tools in the elucidation of the chemistry of the nucleic acids, those remarkable substances that appear to be the very "stuff of life"."

Kunitz was the first to demonstrate that certain enzymes, especially the proteases of mammals, existed in glandular tissues in an inactive form. This formation explained why the tissue proteins were not digested. He went on to study the autocatalytic or catalytic conversion of these precursors to active enzymes following secretion into the digestive fluids.

To present-day biomedical investigators Kunitz may be remembered for having purified the pancreatic nucleases, ribonuclease and deoxyribonuclease which, as Dr Northrop has noted, have become and will continue to be very important in identitying the functions of the various nucleic acids.
During his lifetime, Dr Kunitz received a number of honours including the Carl Neuberg Medal and membership in the National Academy of Sciences. He was made a full member of the Rockefeller Institute in 1950 and became a Professor when the Institute became a University.

Moses Kunitz is survived by a son, Jaques, and a daughter, Rosaline Albert.

Roger M. Herriott

\section{R. K. Murton}

Ron Murton was one of the few really professional scientific ornithologists, who combined careful and patient field observation of birds with rigorous scientific investigation on their anatomy and physiology. His death from a heart attack on 12 June 1978, at the early age of 46 , came as a great shock to his colleagues and friends. Although he had a previous attack some weeks earlier, and had been seriously ill, he had returned to part-time work with his enthusiasm undiminished, and he appeared to be making a good recovery. Up till this spring he had always had such energy and drive, and the ability to work at high pressure sparing neither himself nor his colleagues, that we had never imagined that he would ever suffer from ill health.

Ronald Keir Murton was born in 1932. The first sixteen years of his working life, after graduating in Zoology at University College London, were with the Infestation Control Division of the Ministry of Agriculture, Fisheries and Food. He became immediately involved in the study of birds which are agricultural pests, and with the wood pigeon in particular. The damage done by wood pigeons to brussels sprouts and other brassicae, amounting to many millions of pounds every year, was well known, and the main attempt at control was by supplying cheap cartridges to enable farmers and others to shoot the birds. This gave much pleasure to these sportsmen, but, as Murton soon showed, it had little significant effect on pigeon numbers and it did not prevent the birds from doing economic damage. As a result of his findings the cheap cartridge scheme was stopped, saving the taxpayer a considerable sum of money; farmers whose sport became more expensive were less enthusiastic.

Murton's work on pigeons had a very practical aim, and it was successful in identifying the problems even if it was not possible to find any easy solution. Although the study was what would today be called "customer orientated', it was also (as such studies may be) work of real scientific quality. His observations on pigeon behaviour and reproductive physiology have seldom been equalled. The results are recorded in some 30 scientific papers, in a 'New Naturalist' monograph volume, and they formed the subject of the Barnes Memorial Lecture, which he was invited to give to the Association of Applied Biologists at the unusually early age of 32 .

Although Dr Murton's career was almost entirely in research, he was closely associated with the academic world. In 1968-69 he enjoyed a year's sabbatical leave as a visiting lecturer at the University of Hong Kong. In 1974 he was appointed an Honorary Reader in the department of zoology at Hull University, and recently he was promoted to Honorary Professor. He was in demand to lecture to university students and others.

After leaving Hong Kong he returned briefly to the Ministry of Agriculture in 1969, and then transferred to Monks Wood Experimental Station, at that time under the Nature Conservancy. When the research branch of the Conservancy was reorganised as the Institute of Terrestrial Ecology he remained at Monks Wood, and was soon appointed as Head of the SubDivision of Animal Function.

During the years when he was working on pigeons, which included important observations on feral pigeons in cities, Murton realised the importance of studies of the physiological changes in these birds as a basis for understanding their behaviour and their whole ecology. He became much involved in such topics as the photoperiodic control of the breeding cycle, and other, mainly laboratory, studies. $\mathrm{He}$ considered that these were the logical development of his earlier work. Many colleagues regretted his virtual abandonment of those field studies at which he had been so adept, and thought him ill advised to attach so much importance to his newer investigations. Not all his recent work has had the general approval given to his outstanding pigeon studies. Only time would have shown whether his switch in interest was, as he insisted, wise.

As well as observing birds in the field. Murton was one of the most outstanding bird photographers. As long ago as 1963 he was elected to Associatship of the Royal Photographic Society. During his comparatively short period. just twelve months, in Hong Kong, he made a surprisingly large collection of slides of the nesting habits of many of the rarer and more interesting species, several of which had not been previously photographed. He used his own photographs to illustrate his books and his lectures.

Kenneth Mellanby 